\title{
Research on the Methods of Maximizing the Profits of Enterprise Shareholders
}

\author{
Jie $\mathrm{Li}$ \\ The Affiliated Tianhe School of Guangdong Experimental Middle School \\ 719771965@qq.com
}

\begin{abstract}
In 1999, OECD published a document "OECD corporate governance principles", which stressed that companies should first operate for the interests of shareholders. With the development of science and technology and economy, it has been widely recognized that maximizing shareholders' profits is the primary goal of the company. In the paper, the author conducted a large number of investigations on why the company takes maximizing shareholder profits as its main goal and how to maximize shareholder profits, such as some famous domestic listed companies and elite enterprises in all walks of life. This paper analyzes the reason why companies in various countries changed their strategies in recent years, analyzes the practices and examples of maximizing shareholders' profits, and lastly summarizes several the most effective methods, such as scientific management, evaluation of enterprise value, and maximization of shareholders' profits. It found that these methods are necessary to pay attention to in order to maximize shareholders' profits.
\end{abstract}

Keywords: Shareholder, Shareholder Value, Corporate Governance, Corporate Strategy, Market analysis

\section{INTRODUCTION}

In recent years, shareholder profit maximization has been widely recognized in the financial management industry in western countries and implemented as the primary goal in listed companies. The so-called shareholder profit maximization refers to that when an enterprise considers the time value of money and its corresponding risks, all business decisions take the maximization of shareholder profit as the primary goal of the enterprise. The advantage of maximizing shareholder profit is that it is calculated by the price of the firm's stock market. It not only analyzes the market trend, but also considers the potential risk factors and the time value of money. The trend of the market allows us to better analyze the investment strategy. The level of risk will have a significant impact on the stock price. To a certain extent, the value of money and time can overcome the high-risk actions for most enterprises, such as hoping to make a lot of profits in the short term. The methods of maximizing shareholders' profits have not been involved by too many researchers. This paper will summarize the most effective ways to maximize shareholders' profits by analyzing various methods that can maximize shareholders' profits and the practices of successful enterprises. In view of these methods, the author made some assumptions. First, the author should scientifically manage the company and enterprises, and have a correct value evaluation for the invested enterprises. Then, it is imperative to reasonably analyze the prospects of companies and markets, with a consideration to profit maximization as the goal of financial management.

\section{THE METHOD AND GOAL OF THE COMPANY'S PROFITABILITY}

The profitability of an enterprise refers to the ability of enterprise assets or capital appreciation. Among them, the amount of profit is an important factor affecting profitability. The amount of profit reflects the current or past profit scale or level of the enterprise, but the profitability of the enterprise cannot be judged only by the amount of profit, because the amount of profit can only reflect the overall level or scale of the enterprise's profit, not the formation process of profit in essence. At this point, this paper will introduce the profitability analysis of enterprises. 


\subsection{Measurement indicators to company owners' ability}

The capital operation profitability refers to the owner's ability to make profits through capital operation. The measurement indicators are as follows.

a. Form the perspective of net profit, net assets and debt

If the net profit mainly comes from non-operating income, such as asset disposal, government subsidies, tax exemption, etc. No matter how large the growth rate is, it is only temporary and cannot reflect the real profitability. If the growth rate of net assets cannot reach the growth rate of net profit in the long run, net profit is the "source" of net assets. If it cannot be improved for a long time, the enterprise may falsely increase profits. The higher the debt ratio, the higher the equity multiplier. Increasing the debt ratio to a certain extent will make the leverage too high and rise the system risk, with the exception of high debt industries such as banking and real estate.

\section{b. Analysis on profitability of Commodity Operation}

Through the investigation of several listed companies, the author found that the profitability of commodity operation does not consider the financing or investment of enterprises, but only studies the ratio relationship between profit and income cost.

c. Analysis on the unique profitability of Listed Enterprise

Due to the characteristics of listed enterprises, the profitability can be analyzed not only by the indicators of profitability among general enterprises, but also by some special indicators, such as earnings per share, return on common stock equity, $\mathrm{P} / \mathrm{E}$ ratio, operating cash flow per share, etc.

\section{d. Analysis on profit quality}

Earning quality analysis is a part of profitability analysis. Based on the cash flow statement on the cash basis and through index analysis, the ability of a going-concern enterprise to create stable free cash flow in a certain period can be judged.

Above all, this paper analyzes the profitability of enterprises from four levels. If it is necessary to compare the profitability of different enterprises, the profitability of the enterprise cannot be measured only by the level of a certain index. Besides, key indicators form four levels should be chosen, and the analytic hierarchy process should be used to comprehensively judge the profitability of different enterprises.

\subsection{The company's main goal of maximizing shareholders' profits}

In recent years, shareholder profit maximization has been widely recognized in the financial management industry in western countries and implemented as the primary goal of listed companies. The so-called shareholder profit maximization refers to that when an enterprise considers the time value of money and its corresponding risks, all business decisions take the maximization of shareholder profit as the primary goal of the enterprise. The advantage of maximizing shareholder profit is that it is calculated by the price of the firm's stock market. It not only analyzes the market trend, but also considers the factors of potential risks and the time value of money. Market trends enable people better analyze investment strategies. The level of risk will have a significant impact on the stock price. To some extent, the value of money and time can overcome the high-risk behavior of most enterprises, such as hoping to make a lot of profits in the short term[1].

\section{THE METHODS OF MAXIMIZING SHAREHOLDERS' PROFITS}

\subsection{The ways of shareholders' profits earning}

The major shareholders of the company can make money in three ways: Dividend and cash out which is divided into reduction cash out and stock pledge cash out.

Dividend: Dividends, i.e. interest on shares, refer to the income distributed by the joint stock company to shareholders according to the dividend rate from the after tax profits from the provident fund and public welfare fund. Dividend refers to the distribution of the current year's income to shareholders after withdrawing legal accumulation fund, public welfare fund and other items according to regulations. It is a way of shareholders' income. Generally, after receiving dividends, shareholders will continue to invest in the enterprise to achieve the compound interest. Ordinary shares are entitled to dividends, while preferred shares are generally not entitled to dividends. A joint stock company can only pay dividends when it obtains profits.

Cash out or reduce holdings and cash out: This is an operation for investment, to obtain the liquidity of funds, and to solve the temporary financial difficulties by using idle assets such as securities, such as stocks.

Stock pledge cash out: The full name of stock pledge is the stock pledge type repurchase transaction, which provides qualified funds into the party to pledge the shares held by it, generally to banks or securities companies. The bank or securities Chamber of Commerce will provide funds to the stock pledgor, and both parties will make an agreement that the funds will be returned and the pledge transaction will be canceled in the future. Therefore, the stock pledge is mainly used to solve the problems of capital turnover of listed companies[2]. 
Related party transactions: related party transactions are transactions between related parties of an enterprise. Related party transactions refer to transactions that often occur in the business process of the company and are prone to unfair results. Under the condition of market economy, related party transactions exist widely. From a favorable point of view, due to the relationship between the two parties, a lot of transaction costs can be saved in business negotiation, and administrative power can be used to ensure the priority implementation of business contracts, so as to improve transaction efficiency. On the negative side, because related parties can use administrative power to promote transactions, the price and mode of transactions may be unfair under non-competitive conditions, which will infringe on the rights and interests of shareholders or some shareholders and easily damage the interests of creditors [3].

\subsection{The company's approach to maximizing shareholder profits}

\subsubsection{Scientific management}

To maximize the interests of shareholders, an enterprise with sustainable development ability and competitiveness needs to rely on a set of effective enterprise systems and governance mechanisms. Therefore, a board of directors that can pay attention to the long-term development of the company, care about the interests of all shareholders and operate in place is the core energy of the enterprise. The board of directors with chairman Xie Ming as the core is such a board of directors that makes every effort to safeguard the legitimate interests of the company and minority shareholders.

Additionally, an example of chairman Xie Ming will be analyzed. One of the most important social responsibilities of a listed company is to ensure the interests of shareholders. With its perfect governance structure and standardized operation over the years, Lizhou Laojiao has stood out among more than 1800listed companies, successfully won the two titles of "2010 Best board of directors of listed companies on China's main board" and "2010 best social responsibility board of directors of directors". Among the award-winning enterprises, Luzhou Laojiao ranked first. From 2005 to 2009, Luzhou Laojiao raised 350 million yuan, and the cash dividend reached 2.279 billion yuan. Xie Ming, the chairman of the company, said at the award reception that maximizing the interests of shareholders is always the starting point for the formulation and implementation of all strategies of the company.

An enterprise with sustainable development ability and competitiveness needs to rely on a set of effective enterprise systems and governance mechanisms. Therefore, a board of directors that can pay attention to the long-term development of the company, care about the interests of all shareholders, and operate in place makes the core energy of the enterprise.

Management creates value. When it comes to value rising, Luzhou Laojiao's excellent management thought and strategy are in a higher level. The outstanding characteristics of Luzhou Laojiao's management team in strategy formulation are the courage to reform and being bold in innovation, intervention and risk-taking. This is also the requirement of the changing market and competitive environment for the quality of strategic managers. Luzhou Laojiao adheres to the market value management concept: the premise of pursuing the rise of stock price and winning high market value is to pay close attention to the company's own operation and management and create the company's internal investment value [4].

\subsubsection{Evaluation of enterprise value}

The evaluation of enterprise value refers to that under the condition of continuous operation, the enterprise uses an appropriate discount rate to reflect and accumulate the expected income each year in the future operation period to obtain a certain valuation. As a result, the enterprise value can be estimated. If the enterprise value is greater than the book value of all the assets of the enterprise, the enterprise capital will increase in value. On the contrary, the enterprise will depreciate. Comparing the value obtained by subtracting the enterprise's liabilities from the enterprise value with the book value of the enterprise's shareholders' equity, if the former is greater than the latter, it indicates the appreciation of the enterprise's own capital.

Enterprise value evaluation is one of the important means of enterprise business decision-making. It can help the management effectively improve the level of business decision-making and enable the enterprise to correctly understand the value of the cooperative enterprise. The goal of enterprise financial management is to maximize the interests of shareholders. The feasibility of various business decisions must depend on whether the decision is conducive to increasing enterprise value.

Value evaluation can be used for investment analysis, strategic analysis and value-based management. It can help managers better understand the advantages and disadvantages of the company[6].

At present, the information distortion and low accuracy of China's accounting industry have fundamentally affected the decision-making of enterprise finance department and operation Department. The accounting index system cannot effectively measure the ability of enterprises to create value. This will make the enterprise unable to correctly evaluate its enterprise value. The actual value of an 
enterprise is not equal to its book value. Through the accounting of book value, enterprises are often unable to confirm the value of intangible assets, which is their own valuable wealth accumulated over a long period of development and research. This leads to a key link in the implementation of $\mathrm{MBO}$ - the value evaluation of the target company, that is, the evaluation of the enterprise served by the management, which not only includes the evaluation of the tangible assets of the enterprise, but also covers the evaluation of intangible assets such as technology, management, enterprises and talents. Therefore, enterprise value evaluation helps enterprises pay attention to and carefully verify these accounting distorted information, fully understand the factors of these information, and deal with them correctly, so as to overcome the untrue results of other asset evaluation caused by it. Besides, it can help to avoid factors that lead to the alienation of enterprise value and affect the accuracy of enterprise value.

The financial department must take maximizing enterprise value as the main goal. Through the evaluation of enterprise value, enterprise financial personnel can understand the real value of the enterprise and make scientific investment and financing decisions, so as to continuously improve the enterprise value and the wealth of shareholders [5].

\subsection{3 maximization of shareholders' profits as the goal of financial management}

The maximization of shareholders' profits as the goal of financial management has the advantage that time value and risk value are both considered. It is generally believed that the stock market has the greatest impact on enterprise profits, but the most important thing is the contractual relationship between managers and shareholders. In order to effectively avoid the extreme behavior of enterprises in pursuit of high profits in the short term, it is necessary to link the profits of shareholders with their operating performance, which will be conducive to the preservation and appreciation of capital.

\section{CONCLUSION}

There are three points to pay attention to in order to maximize shareholders' profits, including scientific management, evaluation of enterprise value, and the maximization of shareholders' profits as the goal of financial management. Among them, it is necessary to pay attention to the prediction of the prospect of this market, the analysis and management of the company structure, the clarification of the company and financial objectives. Besides, there are many problems in this paper. For example, the investigation of Listed Companies in the industry is not enough and not comprehensive. There may be some views that are not analyzed comprehensively, and lack integrity and fluency. It is hoped that the sample companies can be comprehensively investigated in the future papers. When writing the paper, the integrity needs to be focused to build a strong connection between each point. Future research will mainly focus on how to maximize the profits of the company and shareholders at the same time, so that shareholders can make money and will not treat employees at lower level badly. This cannot only mobilize the enthusiasm of employees, but also enhance the integrity of the whole company, and enable employees to make sincere efforts for the enterprise. It is suggested that the management and other leaders should listen to the suggestions of subordinates and work together to run the whole company well.

\section{ACKNOWLEDGMENT}

First of all, thank may professor for taking the time to teach us about finance, which makes me learn a lot. The professor's classroom style is lively and interesting. He gives us many examples to help us understand expertise. The professor has also done a good job in teaching, and has a good analysis of knowledge points and examples, so that we can accept relatively simple knowledge. However, due to my network problem, I can't turn on the camera, and I have little communication with the professor, which may not leave an impressive impression on the professor. I apologize for this. I feel very honored to be in your class.

\section{REFERENCES}

[1] Liang Hongqian, On the maximization of shareholders' rights and interests, Market modernization, 2016, pages 76-77.

[2] William Lazonick ， Mary O’Sullivan, Maximizing shareholder value: a new ideology for corporate governance, Economy \& Society, 2000, pages 2-4.

[3] Soymilk 055, Maximization of shareholders' interests, 2019, pages 1-2.

[4] pennyzy111, Maximization of shareholders' interests, 2012, pages 1-3.

[5] bokegood, Analysis on the relationship between corporate social responsibility and maximization of shareholders' interests, Human resources \& Enterprise Management, 2018, pages 4-7.

[6] Li Ying, Wang Wei, Li Qing, Comparative analysis of enterprise value evaluation methods, Science, technology and economy in Inner Mongolia, Issue 204, 2010,pages 5-9. 